Ethiopian Journal of Environmental Studies \& Management 10(5): 654 - 667, 2017.

ISSN:1998-0507

doi: https://dx.doi.org/10.4314/ejesm.v10i5.9

Submitted: March 23, 2017

Accepted: July 03, 2017

\title{
ADOPTION OF IRRIGATION AND ITS CONSEQUENCES ON HOUSEHOLD INCOME IN THE NORTHERN ETHIOPIA
}

WOLDEGEBRIAL ZEWELD, ASSEFA HIDGOT AND GEBRESILASSIE HAILU

Department of Agricultural and Resource Economics, Mekelle University, P. O. Box 231, Mekelle, Ethiopia

\begin{abstract}
An expansion of irrigation is among the priority areas in Ethiopia although farmers' participation is below the expectations. This paper aims to identify factors that affect farmers' decisions to use irrigation and also estimate its role in household income. The data is collected using standardised questionnaire and analysed it using the Heckman model. Household size, rural associations, markets, information access, extension services, and rural roads are found significant factors affecting farmers' decisions to use irrigation. Income from irrigation has accounted for 38\% of total income. Use of irrigation has a significant positive effect on household income. Thus, local associations and institutions should be empowered and rural services should be expanded to induce farmers to use irrigation thereby increases their income.
\end{abstract}

Key Words: Irrigation, income, Heckman model, Ethiopia

\section{Introduction}

Agriculture is a key sector in Ethiopia, which has a lion share in the national gross product (42\%), employment (80\%), foreign exchange earnings $(90 \%)$ and government tax revenue $(30 \%)$. It also creates a niche markets and also provides raw materials for non-agricultural sectors (Gebregziabher et al., 2012; MoFED, 2014). However, its productivity has remained sluggish due to its poor access to improved technologies and agricultural extension services (Bacha et al., 2011; Wubeneh and Sanders, 2006). Family labour and unpredictable natural factors are also other contributing factors (Gebregziabher et al., 2012;
Croppenstedt et al., 2003), which tends to lead to food insecurity and also retards the development of the overall economy (Abebe et al., 2013; Aseyehegu et al., 2011; Tesfay, 2008).

In 1991, the government formulated agriculture-based national policy to bring sustainable economic growth, which focuses on the expansion of irrigation and introduction of technological innovations. To achieve this, the government has allocated about $17 \%$ of the annual budget to this sector. Nongovernmental organisations have been encouraged participating in the construction of irrigation and distribution of improved seed varieties, pesticides and machinery. Farmers' training centres and agricultural

*Corresponding Author: Woldegabriel Zeweld

Email: woldezew@yahoo.com 
extension offices have been established in each village to boost awareness and show farmers their application (MoFED, 2014; Tesfay, 2008; Wubeneh and Sanders, 2006).

Some countries (China, Singapore, Vietnam, Taiwan, India and South Korea), which were experienced severe food insecurity in the 1940s and 1950s, followed similar strategies in the 1970 s and completely moved out of this through the expansion of irrigated areas, and the introduction of high-yielding varieties and chemical fertiliser in the 1960s and 1970s. The same also held in Israel, Iran, Tanzania, Mali, Kenya, Zimbabwe, Ghana and South Africa in the 1980s and 1990s (Timu et al., 2014; Chazovachii, 2012; Fanadzo, 2012; Kuwornu and Owusu, 2012; Dillon, 2011; Bhattarai et al., 2007; Mendola, 2007; Kaliba et al., 2000). There, adoption of irrigation and high-yield varieties was found to significantly improve productivity, reduce consumption shortfall and increase assets.

Because of the national strategies, the irrigated land has increased from $7 \%$ of the potentially irrigable land in 1991 to $25 \%$ in 2009 . The output from irrigated land in 1991 was about $4 \%$ of the total agricultural output whereas it was increased to $31 \%$ in 2009 . Income from irrigation accounted $15 \%$ of the annual income of farmers who involved in irrigation. The number of food-insecure people in the country was falling from $50 \%$ of the population in the 1990 s to $35 \%$ in the 2010s (MoFED, 2014).

However, irrigated land is still small in relation to the potentially irrigable land and compare to other countries; $22 \%$ in Ethiopia, 69\% in Kenya, 57\% in SubSaharan African countries, and $80 \%$ in each Asia and Latin America countries. Use of improved seed varieties, chemical fertilisers and pesticides were also found very low. The reasons were linked to farm size, education, land tenure system, and limited access to credit and extension services (Abebe et al., 2013; Gebregziabher et al., 2012; Aseyehegu et al., 2011; Bacha et al., 2011; MoFED, 2014; Tesfaye et al., 2008; Tesfay, 2008; Wubeneh and Sanders, 2006).

Most studies focused on large-scale irrigation and this study focuses on smallscale irrigation. The number of farmers who have involved in small-scale irrigation has also remained low despite various encouragement. There are many farmers who have irrigated land but don't engage in irrigation. Furthermore, there are few empirical studies about the impact of small-scale irrigation on household income. Such issues instigate for further study and thereof we investigate factors influencing farmers' decisions to participate in small-scale irrigation which represents a scheme (privately or community owned) that can supply water for less than 200 ha command area and also estimate its consequence on farmers' income using Heckman model.

\section{Review of Literature \\ Theoretical and Methodological Framework}

Adoption of technological innovations is based on theoretical frameworks of maximising benefits or minimising costs, and have applied different methodological models; OLS model (linear, log-linear or log-log), which assumed the dependent variable to be a continuous and considered potential users only (Feder and Umali, 1993). 
However, it doesn't fit for the categorical dependent variable and excludes nonusers, which lead to biased and inefficient findings.

Static binary models (Grammatikopoulou et al., 2014; Adeogun et al., 2008; Arellanes and Lee, 2003) or censored regression model (Croppenstedt et al., 2003; Kaliba et al., 2000), which could follow two assumptions; exogenous explanatory variables and only one-way causality between the dependent and independent variables. These models don't detect simultaneities and unobserved heterogeneities, which produce bias, inconsistent and inefficient estimates.

Use of generalized binary models (double-hurdle model, Tobit-limit hurdle model, two-stage ordered probit model) or simultaneous equation models (twostage Heckman, Multinomial logit, bivariate models) to estimate impact of adoption of technologies on welfare (Timu et al., 2014; Abebe et al., 2013; Asfaw et al., 2012; Katengeza et al., 2012; Tesfay, 2008) are methodologically appropriate to address simultaneities and unobserved heterogeneities.

Here we use two-stage Heckman model since the adoption of irrigation is purposefully placed or self-selected, implying decisions to use irrigation is an endogenous variable, and this model accounts for unobserved heterogeneities and simultaneities, in doing so can produce unbiased, consistent and efficient parameters.

The dependent variable is an adultequivalent income (IE), which is the ratio of total income earned by farmers from different sources adjusted for adult equivalent household size. Adult equivalence scale captures age and sex difference in earning and consuming capacities and computed as an adult male and female (15-60 years) is assigned 1; male above 60 years is 0.67 ; female above 60 years 0.60 ; child (10-14 years) is 0.50 ; child (4-9 years) is 0.30 and children below 3 years is economically insignificant (Randela et al., 2000). Accordingly, the functions for those farmers who were and were not participating in irrigation are given by:

$$
\begin{aligned}
& I E_{1 i}(Y)=\alpha_{1 i} Y_{i}+\varepsilon_{1 i} \text { and } \\
& I E_{0 i}(Y)=\alpha_{o i} Y_{i}+\varepsilon_{o i} \quad \varepsilon_{i} \approx N\left(0, \delta^{2}\right)
\end{aligned}
$$

Where $I E_{i}(Y)$ is outcome equation (adult-equivalent income) for farmers $i$, and $Y_{i}$ is a vector of observed attributes like socioeconomic characteristics, biophysical resources and institutional factors. Farmers can participate in smallscale irrigation only if $I E_{1 i}(Y)$ exceeds $I E_{0 i}\left(Y_{i}\right)$ and adult-equivalent income function is given as follows:

$$
I E_{i}=\sum_{i=1}^{n} \alpha_{i} Y_{i}+\eta D_{i}+\varepsilon_{i}, \text { where } D_{i}=\sum_{i=1}^{n} \theta_{i} X_{i}+U_{i}
$$

Where $D_{i}$ represents decisions to use irrigation (selection equation). It is used to construct the selectivity term or Inverse Mills Ratio ( $\lambda$ ), which captures the correlation between unobserved factors in the selection and outcome equations and is included in the outcome equation as an independent variable to 
reflect the degree of sample selection bias, and $\mathrm{X}$ captures factors that influence farmers to use irrigation.

Depending upon the statistical significance of $\lambda$, we can use OLS or Heckman model. A significant value indicates a presence of a sample selection bias (simultaneity and unobservable heterogeneity) and OLS generates bias,

$$
E\left(I E_{i} / D_{i}=1\right)=\sum_{i=1}^{n} \alpha_{i} Y_{i}+\delta_{a u} \delta_{u} \lambda\left(-\theta X_{i}\right)+e_{i}, \text { where }
$$

The Heckman model focuses on the outcome equation and marginal effect of the variables. The conditional marginal effect shows the effect of a given continuous variable on the outcome variable on condition that the household head participates in irrigation schemes. The estimated percentage change in the outcome variable (IE) because of a unit change in $\mathrm{Y}_{\mathrm{k}}$ can be computed from $\{(\exp (\alpha)-1) * 100\}$ where $\alpha$ is the estimated value of the conditional marginal effect of the model.

\section{Empirical Literature and Hypothesis}

A few studies were made in South Africa on factors determining use of irrigation, and its impact on income and food security using a multiple regression. Family size, landholding size, water availability and institutional factors were found to positively influence farmers' decisions to use irrigation. Irrigation had a significant positive contribution to income and food security. Per capita income was increased by $7 \%$ when they moved from non-irrigation to irrigation (Fanadzo, 2012; Oni et al., 2011; Tekana and Oladele, 2011).

Burney and Naylor (2012), Hanjra et al. (2009) and Smith (2004) reviewed several studies. The evidence highlighted that market imperfection, weak inconsistent and inefficient estimates and should use Heckman model. For statistically insignificant value of $\lambda$, there is no sample selection bias and OLS generates better and higher quality parameters (unbiased, consistent and efficient) (Randela et al., 2000). Outcome equation after controlling the Inverse Mill Ratio is given as follows:

$$
\lambda=\frac{\phi\left(\theta, X_{i}\right)}{\psi\left(\theta, X_{i}\right)}=\frac{\phi(-\theta X)}{(1-\psi(-\theta X))}
$$

institutional factors, limited access to improved technologies and poor access to productive assets were the main constraining factors that influence farmers to use small-scale irrigation. Small-scale irrigation was found to increase income, food supply and asset significantly. However, they didn't found strong evidence about the impact of irrigation on poverty reduction.

Other studies in Mali (Dillon, 2011), Zimbabwe (Nhundu et al., 2010), Ghana (Kuwornu and Owusu, 2012; Adeoti, 2009), Kenya (Timu et al., 2014; Mati, 2008), Mozambique (Uaiene et al., 2009), Malawi (Katengeza et al., 2012), Bangladesh (Mendola, 2007), Ethiopia (Gebregziabher et al., 2012; Tesfay, 2008) and Tanzania (Kaliba et al., 2000) also found irrigation had a significant positive contribution to income and food security. Income received from the sales of irrigation products accounted for 20$37 \%$ of total income. Income of irrigation users was $41-79 \%$ higher than counterparts. Mixed findings were found on poverty reduction; significant positive impacts (Nhundu et al., 2010; Katengeza et al., 2012) and insignificant effects (Kuwornu and Owusu, 2012; Dillon, 2011; Mendola, 2007). 
Family size, age, education, land tenure, rural organisations, credits, markets, extension services and rural roads were found among the significant variables that explain use of irrigation. Farm size, land tenure, family schooling and education were positively related to the adoption of irrigation. Education and farmland size had positive impacts on income. Rural associations and rural services could enhance awareness and motivate farmers to use irrigation. Based on the empirical literature, we propose the following hypothesis for farmers' participation in small-scale irrigation (selection equation) and adult-equivalent income (outcome equation).

Table 1: Variable explanation and expected hypotheses for some variables of the study

\begin{tabular}{|c|c|c|c|}
\hline \multirow[b]{2}{*}{ Variable } & \multirow[b]{2}{*}{ Description } & \multicolumn{2}{|c|}{ Prior expectation } \\
\hline & & $\begin{array}{l}\text { Selection } \\
\text { equation }\end{array}$ & $\begin{array}{l}\text { Outcome } \\
\text { equation }\end{array}$ \\
\hline household size & Household size of the household head & $-/+$ & $-/+$ \\
\hline education & $\begin{array}{l}\text { Educational level of the household head ( } 1 \text { for literate and } \\
\text { otherwise } 0)\end{array}$ & + & + \\
\hline livestock & Livestock asset of the household head (TLU*) & + & + \\
\hline farmland & Landholding size of the household head (hectare) & + & + \\
\hline credit & $\begin{array}{l}1 \text { if the farmer has to get credit from rural financial services and } 0 \\
\text { if not }\end{array}$ & + & + \\
\hline information & $\begin{array}{l}1 \text { if the farmer has a television, radio or mobile phones and } 0 \\
\text { otherwise }\end{array}$ & + & \\
\hline membership & $\begin{array}{l}1 \text { if the farmer is a member of formal rural association (water } \\
\text { associations, farmers' associations, cooperative societies) }\end{array}$ & + & \\
\hline extension & Distance to the nearest farmers' training centres $(\mathrm{km})$ & - & \\
\hline markets & Distance to the nearest district/main market $(\mathrm{km})$ & - & - \\
\hline rural functions & $\begin{array}{l}\text { Average distance to rural function, such as primary schools, } \\
\text { health centres, veterinary clinics, bank offices and telephone } \\
\text { booths }(\mathrm{km})\end{array}$ & - & - \\
\hline rural roads & Distance to the nearest all-weather rural roads $(\mathrm{km})$ & - & - \\
\hline water point & Distance to the nearest potable water point for human drink $(\mathrm{km})$ & - & - \\
\hline water source & Distance to reliable irrigation water source $(\mathrm{km})$ & - & - \\
\hline
\end{tabular}

\section{Research Methodology \\ Description of Study Areas}

This study was conducted in the Tigray region, Ethiopia, which extends from $12^{\circ} 1^{\prime}$ to $15^{\circ} 2^{\prime}$ north latitude and $36^{\circ} 46^{\prime}$ to $39^{\circ} 97^{\prime}$ east longitude. The region has six administrative zones, consisting of 35 districts and about 200 villages. Its landmass is about
$41410 \mathrm{~km}^{2}$. Of which, about $49 \%$ is warm temperate, $39 \%$ is semi-arid and $12 \%$ is temperate. The region had about five million populations in 2013 with diversified language and culture. Agriculture is the predominant source of livelihood for more than $75 \%$ of the population. 


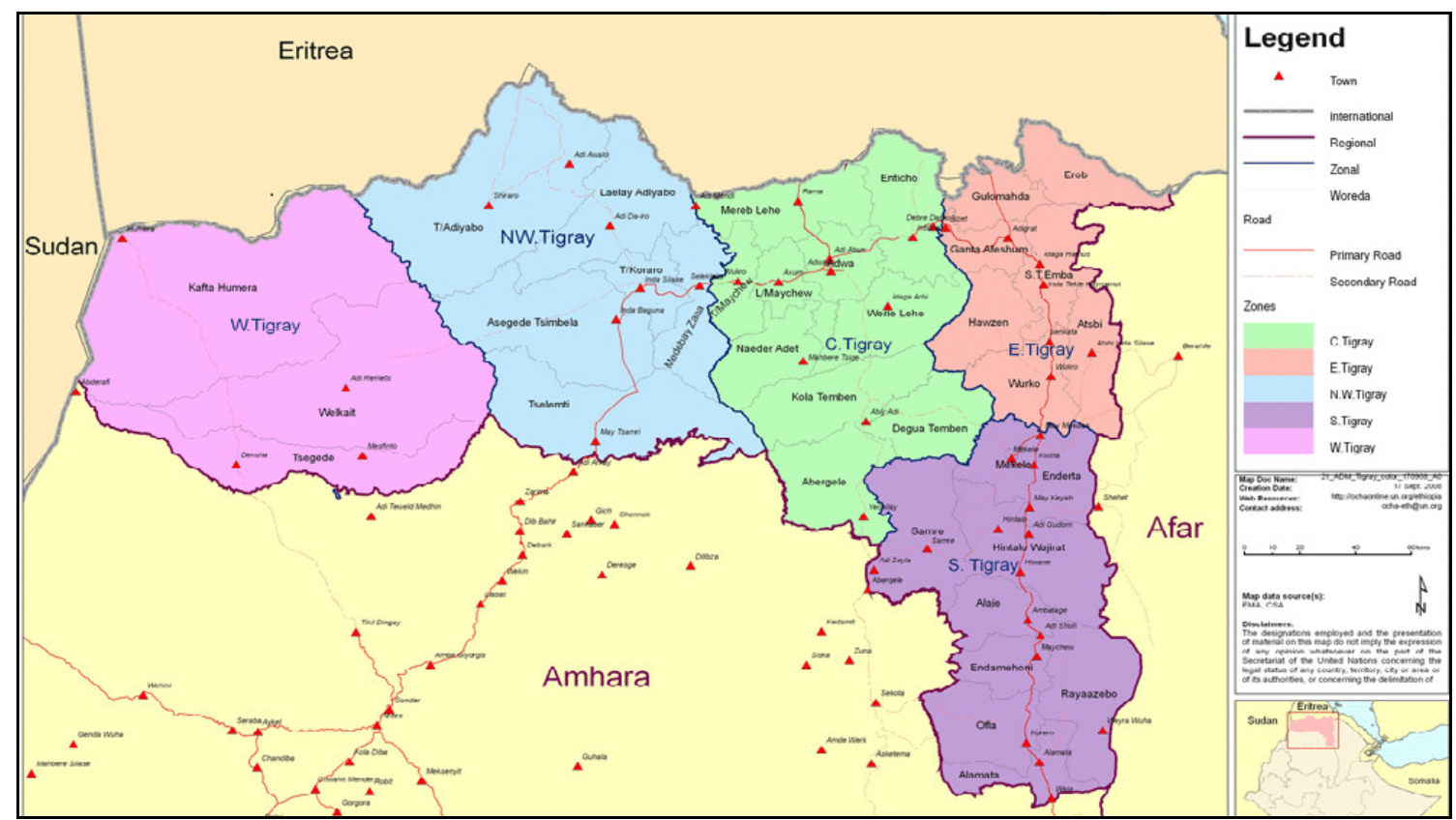

Fig 1: Map of Study Area (https://www.wikipedia.org/tigraymap)

\section{Sample Size and Sample Selection}

The study used a three-stages sampling method to choose sample farmers. First, one district from each administrative zone was randomly selected. Second, two villages were randomly selected from each district. About 400 farmers were randomly selected using proportionate sampling method. The choice of 12 rural villages, although they sufficiently represent the other villages, was associated with a shortage of fund and long-time requirement. Small-scale irrigation schemes, namely, river diversion, spring development, communal dam, ground well and private pond, were selected, which are commonly practised in the region during the survey

Table 2: Distribution of sample farmers at district level

\begin{tabular}{llll}
\hline Districts & Treated group & Control group & Samples \\
\hline Atsbi Wemberta & 43 & 29 & 72 \\
Degua Tembien & 34 & 22 & 56 \\
Endamekoni & 43 & 27 & 70 \\
Kafta Humera & 43 & 27 & 70 \\
LaelayMaichew & 40 & 26 & 66 \\
Tahtay Koraro & 37 & 29 & 66 \\
\hline Sample size & 160 & 240 & 400 \\
\hline
\end{tabular}

\section{Data Collection and Analysis Methods}

The study collected a cross-sectional data using a questionnaire, which was pre-tested by 10 randomly selected farmers to check the adequacy of the questions and determine the ability of farmers in answering questions. The data were analysed differently to capture the objectives and produce valid research outputs. The Heckman model is used to 
identify the factors that explain farmers' participation in irrigation and its consequence on household income.

\section{Results and Discussion Profile of Respondents}

The data used in this research is originated from a household survey in 2013. The exploratory analysis shows that about $40 \%$ of the respondents have been involved in small-scale irrigation (treated group) and the remaining did not (control group). This counterfactual is used to understand impacts of small-scale irrigation on income. In the areas, rivers, springs, dams, wells and ponds are the main sources of irrigation water and about $31 \%, 19 \%, 22 \%, 16 \%$ and $12 \%$ of the treated farmers were respectively involved in river diversion, communal dam, spring development, groundwater well and private pond small-scale irrigation.

Agriculture was the primary occupation for more than $50 \%$ of the respondents while the figure in the region was $75 \%$ (MoFED, 2014). More than $60 \%$ were male-headed households. The average age was about 45 years. The average livestock asset and landholding size were about $3.5 \mathrm{TLU}$ and $0.63 \mathrm{ha}$, respectively. About $55 \%$ of the samples were literate. The mean household size was 6 persons. About 32\% and 38\% of the control and treated households owned irrigated farmland. About $62 \%$ of the treated group didn't own irrigated farmland, rather, either rented in or sharecropped-in irrigated land from others who have irrigated farmland.

Two sample t-test shows insignificant differences in age, gender, and primary occupation nor in landholding size between the treated and control households at $5 \%$ level. These variables may not bring a significant difference in decisions to use irrigation. However, there was statistically a significant difference in household size, education level of the head and livestock between the treated and control farmers. Apparently, the treated households have relatively a larger household size and more livestock than the control households. The literacy rate was higher for the treated households than the control households. These variables may lead to bias results in the adoption decision of irrigation among the farmers.

Table 3: Characteristics of treatment and non-treatment farmers (at percent or mean level)

\begin{tabular}{|c|c|c|c|c|c|}
\hline \multirow{2}{*}{ Variables } & \multicolumn{2}{|c|}{ Chi-square test (\%) } & \multicolumn{2}{|c|}{ Two-sample t-test } & \multirow{2}{*}{ P-value } \\
\hline & Treated & Control & Treated & Control & \\
\hline Male-headed household & 70 & 63 & & & 0.078 \\
\hline Agriculture as primary occupation & 60 & 52 & & & 0.093 \\
\hline Literate household head & 59 & 49 & & & $0.021 * *$ \\
\hline Household with irrigated land & 38 & 32 & & & NA \\
\hline Household head age (years) & & & 44 & 46 & 0.186 \\
\hline Household size & & & 7.0 & 6.0 & $0.048^{* *}$ \\
\hline Livestock asset (TLU) & & & 3.9 & 3.0 & $0.037 * *$ \\
\hline Landholding size & & & 0.58 & 0.68 & 0.084 \\
\hline Distance to rural functions (min) & & & 89.4 & 94.2 & 0.535 \\
\hline
\end{tabular}


Adoption of Irrigation and its Consequences on Household Income.................ZEWELD et al.

\section{Small Scale Irrigation as Source of Income}

Irrigation can provide additional income for rural communities. The treated households have earned more net income from selling of crops, fruits, vegetables and residuals. The mean annual income from a private pond was Birr 4500 and Birr 2576 from river diversion. The treated households with spring water have earned Birr 3789 annually.

Irrigation income share, which is the proportion of income from irrigation activities to the total income of the household in 2012/13, was significant. For example, income from river diversion, spring, ground well, private pond and communal dam respectively accounted for about 38\%, 50\%, 43\%, $53 \%$ and $42 \%$ of total income of the treated households. The mean income from irrigation was about $45 \%$ of total income.

Similar findings were reported in other countries; Nigeria, Zimbabwe, and Ghana, where irrigation income accounted for about $30-40 \%, 20 \%$ and $30 \%-50 \%$ of income of the treated households, respectively (Kuwornu and Owusu 2012; Oruonye 2011; Nhundu et al. 2010). Thus, small-scale irrigation is an important source of income for farmers.

Table 4: Mean Income from Irrigation for the Treated Household (Birr)

\begin{tabular}{lccc}
\hline Type of irrigation & Irrigation income & Total income & Irrigation income share \\
\hline River diversion & 2576 & 6780 & 38 \\
Spring water & 3789 & 7602 & 50 \\
Groundwater well & 2809 & 6535 & 43 \\
Private pond & 4510 & 8543 & 53 \\
Communal dam & 2369 & 5592 & 42 \\
\hline Mean income & 3210 & 7010 & 45 \\
\hline
\end{tabular}

We also compared income difference between the treated and control households using two-sample t-test. Table 5 describes that the mean income for the treated group was Birr 7030 while for the control group was Birr 5868. The mean income of the treated was $20 \%$ higher than that of the control. The twosample t-test shows a significant difference in adult-equivalent income between the treated and control households.
This was related to other findings; income of farmers who have engaged in small-scale irrigation in Zimbabwe was $12 \%$ higher than the income of farmers who didn't participate in irrigation (Nhundu et al., 2010). The annual per capita income of irrigation farmers in South Africa was about $27 \%$ higher than non-irrigation farmers (Oni et al., 2011; Tekana and Oladele, 2011). Consequently, irrigation user farmers can earn a higher income than the counterparts.

Table 5: Mean income difference of farmers using two-sample t-test method (Birr)

\begin{tabular}{lcccc}
\hline Variables & Treated group & Control group & Difference $(\%)$ & P-value \\
\hline Mean income earning & 7030 & 5868 & $20 \%$ & $0.0021^{* * *}$ \\
Adult equivalent income & 1977 & 1390 & $42 \%$ & $0.0059^{* * *}$ \\
\hline
\end{tabular}




\section{Adoption Decisions to use Small-scale Irrigation}

This section explores factors that affecting farmers to use small-scale irrigation. Table 6 shows that labour supply, distance to irrigation water point, membership in rural associations, information access, distance to farmers training centres, distance to district market and distance to all-weather rural roads were found important factors in influencing farmers to use small-scale irrigation. This was partly related to previous studies.

Distance to rural roads, education, distance to markets, distance to rivers, household size, information access, peasant associations, and training were essential variables that determining participation in irrigation. Contrary to our study, these studies found that livestock units, gender and age of the head, and credit access were found to significantly explaining farmers' participation in small-scale irrigation (Kuwornu and Owusu, 2012; Aseyehegu et al., 2011; Bacha et al., 2011; Dillon, 2011; Swamikannu and Berger, 2009).

Membership in rural associations has a significant positive effect in adopting small-scale irrigation. The probability of participating in irrigation was $37 \%$ higher for farmers who are members of rural associations than those who are not members because the local institutions could teach members about the importance of irrigation. This result was the same as to our prior expectation, and other studies in Ethiopia, Zimbabwe and Kenya (Chazovachii, 2012; Aseyehegu et al., 2011; Mati, 2008).

It was found a significant positive effect of household size on adoption decisions. An additional member in the household size increased the probability to participate in irrigation by about $21 \%$. A large family size has a higher probability of using irrigation than a small family size because irrigation is highly labour demanded. Similar findings were found in Ethiopia and Kenya. A unit increase in household size increased the likelihood to participate in small-scale irrigation by more than $30 \%$, keeping other variables at their mean levels (Timu et al., 2014; Aseyehegu et al., 2011; Bacha et al., 2011; Mati, 2008; Tesfay, 2008).

Access to information was another important factor in the adoption decisions. Farmers who have information access (radio, television or extension services) have $32 \%$ higher probability of using small-scale irrigation than the other farmers. The sign was similar to the prior hypothesis. Aseyehegu et al. (2011) and Mati (2008) report similar findings in Ethiopia and Kenya: more than $70 \%$ of irrigation users and $35 \%$ of irrigation nonusers had access to fixed telephone and mobile phones. However, Oruonye (2011) found a contradictory finding. The value of communication facilities and mass media had a weak/insignificant effect in irrigation. Thus, information may or may not motivate farmers to participate in small-scale irrigation.

Rural social and physical services can improve understanding of people about technological innovations (Grammatikopoulou et al., 2014; Feder and Umali, 1993). Rural functions had insignificant effects to influence farmers to use irrigation because they were unvaryingly distributed across the districts. Every individual has access to these functions. Farmers' training centres are important sources of 
information/awareness. As one $\mathrm{km}$ increased in the average distance to farmers' training centres, the probability of farmers to involve in small scale irrigation decreased by about $2 \%$. Oruonye (2011) and Tesfaye et al. (2008) reported similar findings on agricultural extension services and opposite findings on rural functions.

Proximity to irrigation water point has a significant positive relationship to farmers' use of small-scale irrigation. Keeping other variables constant, the probability of farmers to participate in small-scale irrigation increased by about $7 \%$ with one $\mathrm{km}$ reduction in the average distance from the irrigated farmland to irrigation water sources. This finding was the same as we hypothesised. The shorter the distance to the place where reliable irrigation water source found, the higher would be the probability of farmers to participate in small-scale irrigation.

The distance to district markets and all-weather rural roads negatively influenced the probability to use irrigation. One $\mathrm{km}$ increased with mean distance to markets and rural roads, the likelihood to use small-scale irrigation reduced by about $7 \%$ and $8 \%$ because of the opportunity cost of time and transaction costs. Grammatikopoulou et al. (2014), Bacha et al. (2011), Swamikannu and Berger (2009) and Bhattarai et al. (2007) also reported similar results. Farmers who live far away from district markets and allweather rural roads have limited information access and therefore have a lower probability to participate in smallscale irrigation.

\section{Impact of Small-scale Irrigation on Income}

This section investigates the effect of irrigation on household income. In Table 6 , the value of $\lambda$ is 0.1 and is statistically significant, indicating a presence of selection bias. Farmers who are participating in irrigation are not randomly assigned. Adult-equivalent income has suffered from simultaneities and hidden heterogeneities and thereof Heckman model is appropriate to address selection bias and capture the impact of irrigation on income effectively.

The findings show that 10 variables (education, household size, livestock, landholding size, credit access, markets, rural functions, potable water point, rural roads and selectivity effect) were significantly explaining adult-equivalent income, which was 5\% higher for literate farmers than illiterate farmers while it was increased by $6 \%$ and $2 \%$ with an increasing of livestock asset by 1TLU and landholding size by a hectare. Adultequivalent income was falling by $5 \%$ with an additional of one member in the household size, suggesting household size has a negative effect while education, livestock and landholding size have positive effects on adult-equivalent incomes.

Adult-equivalent income was increasing by $3 \%, 2 \%, 1 \%$ and $2 \%$ with one $\mathrm{km}$ reduction in the mean distance to rural roads, rural functions, drinking water and markets, respectively. Unlike the hypothesis, credit access was found to have a significant negative impact on adult-equivalent income. Farmers who have no credit access because of several factors (personal, institutional or economic reasons) have $4 \%$ higher adult- 
equivalent income than farmers who have access.

We checked whether this was due to the difference in household size but we found this was not because total income was even higher by $9 \%$. The reason for the opposite finding may be due to a misallocation of loans for unproductive or unplanned purposes, frequent droughts may adversely affect assets that farmers brought by the loans and a high rate of interest, which may lead to high repayment burden, enable farmers to sell their productive assets to repay the loans.

Irrigation can help farmers to overcome rainfall variability and water stress. A sustainable supply of water can relieve them from a high dependence on natural rainfall and can improve productivity and production. However, during the survey, not all farmers have engaged in irrigation, even those who have irrigated land. The reasons were linked to several factors, namely, non- membership in rural associations, limited labour supply, lack of agricultural information and unreliable irrigation water sources. During the survey, adultequivalent income for those who have engaged in irrigation was about $10 \%$ higher than the counterparts.

This finding was consistent with others. In Ethiopia, irrigation has a significant positive effect on income (Asfaw et al., 2012; Bacha et al., 2011; Tesfay, 2008). Using mean income as a proxy variable for food security, about $70 \%$ of irrigation users were food secure while about $20 \%$ of irrigation non-users were found to be food secure (Tesfaye et al., 2008). In Ghana and South Africa, both Heckman and OLS models show that adoption of irrigation had a significant positive effect on income (Adeoti, 2009), and on income, consumption and food security (Fanadzo, 2012).

Table 6: Estimated Coefficients of the Heckman Selection Model

\begin{tabular}{|c|c|c|c|c|}
\hline \multirow[b]{2}{*}{ Variables } & \multicolumn{2}{|c|}{ Selection equation } & \multicolumn{2}{|c|}{ Outcome equation } \\
\hline & $\begin{array}{l}\text { Probability of } \\
\text { participation }\end{array}$ & $\begin{array}{l}\text { Conditional } \\
\text { marginal effect (\%) }\end{array}$ & $\begin{array}{l}\text { Coefficient } \\
\text { parameters }\end{array}$ & $\begin{array}{l}\text { Conditional } \\
\text { marginal effect }(\%)\end{array}$ \\
\hline membership & $0.1153 * * *$ & $37.53 * * *$ & & \\
\hline education & & & $0.0466 * * *$ & $4.773 * * *$ \\
\hline household size & $0.5344 * *$ & $20.91 * *$ & $-0.0466 * *$ & $-4.555 * *$ \\
\hline livestock & & & $0.0538 * *$ & $5.524 * *$ \\
\hline farmland & & & $0.0213 * * *$ & $2.153 * * *$ \\
\hline credit & & & $-0.0417 * *$ & $-4.082 * *$ \\
\hline information & $0.8298 * * *$ & $31.86 * * *$ & & \\
\hline extension & $-0.0450 * * *$ & $-1.70 * * *$ & & \\
\hline markets & $-0.2903 * * *$ & $-10.97 * * *$ & $-0.0178 * *$ & $-1.762 * *$ \\
\hline watersource & $-0.1838 * *$ & $-6.87 * *$ & & \\
\hline waterpoint & & & $-0.0124 * * *$ & $-1.229 * * *$ \\
\hline rural function & & & $-0.0161 * *$ & $-1.598 * *$ \\
\hline rural road & $-0.2236 * *$ & $-8.45 * *$ & $-0.0336 * *$ & $-3.303 * *$ \\
\hline Inverse Mills ratio & & & $0.0972 * * *$ & $10.211 * * *$ \\
\hline Wald $X^{2}(\rho=0)$ & & & $18.54 * * * *$ & \\
\hline
\end{tabular}




\section{Conclusion}

The theme of this study is to identify factors that explain farmers' decisions to use small-scale irrigation and estimate its impact on household income. We find labour supply, group membership, information access, irrigation water availability, extension services, markets and all-weather rural roads to be significant factors influencing farmers' decisions to participate in irrigation. Small-scale irrigation has a significant positive effect on adult equivalent household income, suggesting possibilities to raise income through small-scale irrigation. We suggest that rural organisations (farmers' associations, cooperative societies and neighbouring networks) should be empowered and strengthened. Information centres (farmers training centre and extension service offices) should be equipped with necessary facilities. Social institutions such as schools and clinics should be expanded to improve awareness of farmers and motivate them to use irrigation to maximise their yields and income.

\section{References}

Abebe, G., Bijman, J., Pascucci, S. and Omta, O. (2013). Adoption of improved potato varieties in Ethiopia: the role of agricultural knowledge and innovation system and smallholder farmers' quality assessment. Agricultural Systems, 122: 22-32.

Adeogun, O.A., Ajana, A.M. Ayinla, O.A., Yarhere, M.T.and Adeogun, M.O. (2008). Application of Logit Model in adoption decision: a study of hybrid Clarias in Lagos State, Nigeria. American-Eurasian Journal of Agriculture and Environmental Sciences, 4(4): 468-472.
Adeoti, A.I. (2009). Factors influencing irrigation technology adoption and its impact on household poverty in Ghana. Journal of Agriculture and Rural Development in the Tropics and Subtropics, 109(1):51-63.

Arellanes, P. and Lee, D.R. (2003). The determinants of adoption of sustainable agriculture technologies: evidence from the hillsides of Honduras. Proceedings of the 25th International Conference of Agricultural Economists, (August), pp.693-699.

Aseyehegu, K., Yirga, C. and Rajan, S. (2011). Effect of small-scale irrigation on the income of rural farm households: the case of LaelayMaichew District, Central Tigray, Ethiopia. Journal of Stored Products and Postharvest Research, 2(10): 208-215.

Asfaw, S., Shiferaw, B., Simtowe, F. and Lipper, L. (2012). Impact of modern agricultural technologies on smallholder welfare: Evidence from Tanzania and Ethiopia. Food Policy, 37(3): 283-295.

Bacha, D., Namara, R., Bogale, A. and Tesfaye, A. (2011). Impact of smallscale irrigation on household poverty: empirical evidence from the Ambo district in Ethiopia. Irrigation and Drainage, 60(1): 1-10.

Bhattarai, M., Barker, R. and Narayanamoorthy, A. (2007). Who benefits from irrigation development in India? implication of irrigation multipliers for irrigation financing. Irrigation and Drainage, 56: 207-225.

Burney, J.A. and Naylor, R.L. (2012). Smallholder irrigation as a poverty alleviation tool in Sub-Saharan Africa. World Development, 40(1): 110-123. 
Chazovachii, B. (2012). The impact of small-scale irrigation schemes on rural livelihoods: the case of Pangani Irrigation Scheme Bikita District Zimbabwe. Journal of Sustainable Development in Africa, 14(4); 217231.

Croppenstedt, A., Demeke, M. and Meschi, M. (2003). Technology adoption in the presence of constraints: the case of fertilizer demand in Ethiopia. Review of Development Economics, 7(1): 5870.

Dillon, A. (2011). The effect of irrigation on poverty reduction, asset accumulation, and informal insurance: Evidence from Northern Mali. World Development, 39(12): 2165-2175.

Fanadzo, M. (2012). Revitalisation of smallholder irrigation schemes for poverty alleviation and household food security in South Africa: A review. African Journal of Agricultural Research, 7(13): 1956-1969.

Feder, G. and Umali, D.L. (1993). The adoption of agricultural innovations: A review. Technological Forecasting and Social Change, 43: 215-239.

Gebregziabher, G., Namara, R.E. and Holden, S. (2012). Technical efficiency of irrigated and rain-fed smallholder agriculture in Tigray, Ethiopia: A Comparative Stochastic Frontier Production Function Analysis. Quarterly Journal of International Agriculture 51, 51(3): 203-226.

Grammatikopoulou, I., Pouta, E. and Myyrä, S. (2014). Exploring the determinants for adopting water conservation measures. What is the tendency of landowners when the resource is already at risk?, Helsinki, Finland: MTT Agrifood Research Finland, Economic Research Unit.
Hanjra, M. a., Ferede, T. and Gutta, D.G. (2009). Reducing poverty in subSaharan Africa through investments in water and other priorities. Agricultural Water Management, 96: 1062-1070.

Kaliba, A.R.M., Verkuijl, H. and Mwangi, W. (2000). Factors affecting adoption of improved maize seeds and use of inorganic fertilizer for maize production in the intermediate and lowland zones of Tanzania. Journal of Agricultural and Applied Economics, 32: 3-47.

Katengeza, S., Mangisoni, J.H., Kassie, G.T., Sutcliffe, C., Langyintuo, A.S., La Rovere, R. and Mwangi, W.M. (2012). Drivers of improved maize variety adoption in drought prone areas of Malawi. Journal of Development and Agricultural Economics, 4(14): 393-403.

Kuwornu, J. and Owusu, E. (2012). Irrigation access and per capita consumption expenditure in farm households: Evidence from Ghana. Journal of Development and Agricultural Economics, 4(3): 78-92.

Mati, B.M. (2008). Capacity development for smallholder irrigation in Kenya. Irrigation and Drainage, 57: 332-340.

Mendola, M. (2007). Agricultural technology adoption and poverty reduction: A propensity score matching analysis for rural Bangladesh. Food Policy, 32: 372393.

Ministry of Finance and Economic Development (MoFED) (2014). Growth and Transformation Plan: Evaluation of Five Years Strategic Plan of Ethiopia (2011-2015) by Ministry of Finance and Economic Development, Addis Ababa, Ethiopia. 
Nhundu, K., Gwata, C. and Mushunje, A. (2010). Impacts of ZimbabweEuropean Union micro-project programme (Zim/Eu MPP) in funding smallholder irrigation projects on food security and income levels: a case study of Mopane irrigation scheme in Zvishavane, Midlands province, Zimbabwe. African Journal of Agricultural Research, 5(14): 17591771.

Oni, S., Maliwichi, L. and Obadire, O. (2011). Assessing the contribution of smallholder irrigation to household food security, in comparison to dryland farming in Vhembe district of Limpopo province, South Africa. African Journal of Agricultural Research, 6(10): 2188-2197.

Oruonye, E.D. (2011). An assessment of Fadama dry season farming through small-scale irrigation system in Jalingo LGA, Taraba state. International Research Journal of Agricultural Science and Soil Science, 1(1): 14-19.

Randela, R., Frikkie, L., Johann, K. and Rob, T. (2000). Demand for livestock tick control service in the Venda Region, Northern Province. Agrekon, 39(4): 644-655.

Smith, L., 2004. Assessment of the contribution of irrigation to poverty reduction and sustainable livelihoods. Water Resources Development, 20(2): 243-257.

Swamikannu, N. and Berger, T. (2009). Impacts of small-scale irrigation on poverty dynamics in the white-Volta basin of Ghana: an integrated multi- agent simulation approach. In IHDP Open Meeting. Human Dimensions of Global Environmental Change, Bonn, Germany, pp. 1-20.

Tekana, S.S. and Oladele, O.I. (2011). Impact analysis of Taung irrigation scheme on household welfare among farmers in the north-west province, South Africa. Journal of human ecology, 36(1): 69-78.

Tesfay, H. (2008). Impact of irrigation development on poverty reduction in northern Ethiopia. $\mathrm{PhD}$ thesis, National University of Ireland, Cork.

Tesfaye, A., Bogale, A., Namara, R. and Bacha, D. (2008). The impact of smallscale irrigation on household food security: The case of Filtino and Godino irrigation schemes in Ethiopia. Irrigation and Drainage Systems, 22: 145-158.

Timu, A., Mulwa, R., Okello, J. and Kamau, M. (2014). The role of varietal attributes on adoption of improved seed varieties: the case of sorghum in Kenya. Agriculture \& Food Security, 3(1): 9.

Uaiene, N., Arndt, C. and Masters, W. (2009). Determinants of agricultural technology adoption in Mozambique. Discussion papers No. 67E, National Directorate of Studies and Policy Analysis, Ministry of Planning and Development, Republic of Mozambique.

Wubeneh, N.G. and Sanders, J.H. (2006). Farm-level adoption of sorghum technologies in Tigray, Ethiopia. Agricultural Systems, 91: 122-134. 